\title{
The Ire of Satire Meets the Error of Terror
}

\author{
by Biko Agozino
}

Virginia Tech

Sociological Research Online, 20 (4), 8

$<$ http://www.socresonline.org.uk/20/4/8.html>

DOI: $10.5153 /$ sro.3791

Received: 23 Jan 2015 | Accepted: 24 Aug 2015 I Published: 30 Nov 2015

\begin{abstract}
The reign of terror named terrorism as a state ideology during the French revolution but the practice of terrorism as public policy predated cries of liberte, egalite et fraternite, given the unprecedented peculiar history of Maafa or the African holocaust that went on for centuries, first across the Sahara and then across the Atlantic, under the sponsorship of various states. The error in terrorism is that it presumes that human beings are such scary cats that fear would be an effective policy for domination or liberation. On the contrary, human beings are a strange piece of work capable of facing the scariest threats even with a thrill of heroism or a yearning for martyrdom. The error in terrorism is that the state continues to fight fire with fire, a crazy form of vaccination by which the lethal doze of the disease is prescribed as the panacea for the virus. The error in anti-terrorism terrorism is that terrorists are not afraid to die and often crave martyrdom whether they are stateless or be-medaled agents of a state while the state frequently sponsors its own favorite terrorists against chosen enemies in proxy wars that tend to boomerang.
\end{abstract}

Keywords: Terror, Error, Satire, Ire, Imperialism, Africa

1.1 The reign of terror named terrorism as a state ideology during the French revolution ${ }^{1}$ ] but the practice of terrorism as public policy predated cries of liberte, egalite et fraternite, given the unprecedented peculiar history of Maafa or the African holocaust that went on for centuries, first across the Sahara and then across the Atlantic, under the sponsorship of various states. [2] The error in terrorism is that it presumes that human beings are such scary cats that fear would be an effective policy for domination or liberation. On the contrary, human beings are a strange piece of work capable of facing the scariest threats even with a thrill of heroism or a yearning for martyrdom. The error in terrorism is that the state continues to fight fire with fire, a crazy form of vaccination by which the lethal doze of the disease is prescribed as the panacea for the virus. The error in anti-terrorism terrorism is that terrorists are not afraid to die and often crave martyrdom whether they are stateless or bemedaled agents of a state while the state frequently sponsors its own favorite terrorists against chosen enemies in proxy wars that tend to boomerang, according to Michael Mann .[3]

1.2 Satire believes that laughter is the best medicine for the error in terror but the ire in satire provokes the terror of the bullied against those who sat there taunting the targets of satire and stoking the fire of their ire. It would have been easier to fight satire with satire but there are all sorts of laws proscribing certain speeches and there are all sorts of resources to ensure that ire for ire does not carry equal weight in circulation and consumption. When the state sponsors millions of copies of the postmortem issue of Charlie Hebdo, a moribund racist rag that prides itself with the deliberate inability to draw any picture realistically perhaps because it is unnecessary to do so in order to lampoon or caricature the sacred beliefs of others, there is no level playing field for the offended who have no access to funding for millions of copies of the rebuttal.

1.3 Growing up in Nigeria as a child who survived a genocidal war in which 3.1 million people were killed mainly through what the genocidal pseudo intellectuals continue to defend as 'a legitimate weapon of war' starvation - but through the mediation of weapons of mass destruction generously supplied by UK and Soviet Union to enable more small arms to be discharged in 30 months than in the five years of the European tribal 
World War II, 44$]$ I can testify that the inerrantPope Francis was not entirely mistaken in his assertion that mothers are so sacred that if you abuse his mother, he deserves every right to punch you in the face. Similarly, having witnessed so much violence in Biafra, we knew as children that abusing the mother of another was not the worst provocation ever but it could still lead to a punch-up. We played a mutual game of provocation in which two people abused each other's mother to see who would lose the game by responding with ire rather than with satire, by resorting to the error of terror instead of self-mocking laughter. We called the game, Njakiri, and occasionally it led to fist fights that were settled by allowing the two combatants to punch each other out while the spectators cheered them on. African Americans have similar games of 'playing the dozen'[5] which goes along the lines of 'your mother so dumb...' and that too could lead to fist fights when someone refused to take something back but not necessarily to drive-by shooting or the error of terror given that the African Diaspora has gone through peculiar provocations for centuries of chattel slavery during which mothers were ravished in the presence of their children and the children fathered by the rapists were then sold as property by the dead-beat enslaving father-terrorists.

The puzzle is that when Africans take up arms to fight, it is almost always against fellow Africans as the attackers of Charlie Hebdo made sure that they went back to shoot the police officer of African descent in the head to ensure that he was dead and the Kosher Supermarket attacker earlier killed an unarmed black woman from Martinique who was in police uniform. As Muslim leaders are often complaining, the error of terrorism by those who claim to be fighting on behalf of Islam is that they end up killing more Muslims than anyone else. Al Shebaab militants in Somalia and Boko Haram terrorists in Nigeria are similar in the sense that they sometimes give the impression of separating Muslims from Christians before massacring the latter but overall they both kill Muslims and Christians indiscriminately.

The question here for sociological theory is why people of African descent managed to survive centuries of the reign of patriarchal imperialist white supremacist terrorism and the Igbo survived the Biafra genocide but there was no longing for the error of terror or even the ire of satire as a responsible strategy against the unfathomable unprovoked provocations? Instead, these victimized groups have apparently survived by forgiving the perpetrators and by trying to move on with their lives with relative success compared to other groups with perceived wrongs who have adopted the error of terror as the preferred mode of response only to deepen the crises facing such groups as terror begets terror and error begets more errors as ire for ire and fire for fire become the rule. The answer may lie in the Africana practice of forgiving the unforgivable which Derrida tried to trace to the Abrahamic traditions of the religions of the book but Derrida failed because all such faiths always specify that there is a category of the unforgivable offense that could not be forgiven[6] despite the brazen lie on the cover of the postmortem issue of Charlie - 'All is forgiven'.

1.6 Rather than forgive all, European security forces went into a hysterical ire in defense of the right to publish satires but with the familiar error of terror as a strategy against terrorism. It was reported that fifty people were arrested in France, including students who did not feel that 'Je Sui Charlie' was an accurate description of their names while Belgium killed two suspects and arrested over a dozen citizens suspected of returning from the war in Syria with the alleged intention to use the error of terror to target police officers. In the UK, Home Secretary Theresa May, doubled down on her error of terror warnings against universities that nanny told to mind what they taught, a fatal strategy she has been echoing since the mass uprising in North Londonfollowing the killing of an innocent black man by police officers who suspected him of drug-dealing; repeated when two Islamic militants, Michael Adebolajo and Michael Adebowale, slaughtered a soldier, Drummer Lee Rigby, on the streets of London, and again after the Paris killings in 2015, in spite of warning from the opposition not to mess with academic freedom. ${ }^{[7]}$

1.7 Sociologists need to educate policy-makers that universities were never the hot-beds of terrorism but actually the terrain for informed discourse where the right to free speech means that you support the right of those you disagree with to air their views and give you the opportunity to counter rather than try to scare opponents into silence with the error of terror as state policy, as Noam Chomsky has been arguing. ${ }^{[8]}$ In other words, rather than seek to build fortress universities, Theresa May should be seeking to encourage more diversity among the professortariate to ensure robust debates among scholars who may disagree in all things while agreeing with Winston Churchill that to jaw jaw is better than to war war When the UK has only 50 professors of colour out of over 10,000 professors, according to Cornel West, it is likely that disaffected youth would not find alternative role models that could channel their youthful angst into productive intellectual debates but increasingly drift towards unaccountable old men who claim unquestionable authority over their impressionable minds whereas their university professors would have been inviting dissent on all issues for a robust culture of scholarly debate and non-violent struggles. 

(rather than the prized tactic of having the attacking strikers score goals on the pitch) could happen at the end of the $20^{\text {th }}$ century and he came to the conclusion that the media are to blame because of their error of using terror to market programs to the public who are obsessed with the media ability to be present even before the start of the terror in order to capture it live. In his view, this works because reality has been murdered by the simulacrum, truth has been assassinated by the principle of evil; what matters is no longer what is true and what is false but what is good and what is evil, making media representations of evil very popular because evil is transparent enough to make one person's good to be seen as another person's evil.[9] Here, Baudrillard may have overstated his postmodernist thesis on the error of terrorism as a fatal strategy for even when there are no media reporters to cover the events live as in Northeast Nigeria where Boko Haram is running rough shod and killing thousands of people while kidnapping hundreds of young girls to be used as sex slaves, the absence of television cameras does not make those events non-events although the Boko Haram and the Jihadi Johns of ISIS who behead hostages make sure that they share the images on social media as if to validate the theory of the simulacra by making their evil acts transparent as part of the error in terror in the mass media.

1.9 Rather than buy a Marshal McLuhan[10] suggestion that the media have turned the world into a global village in which wars (against terror, for instance) will be fought with mainly information technology, it is necessary to consider the fact that the error in terror is a deliberate brutal error by the modern state that still believes in the fatal strategy of the reign of terror especially against the citizens of less powerful states only to suffer the blow-back when the chickens come home to roost. For instance, the US was known to have engaged in the training and arming of the people of the book, the Taliban, in Afghanistan when it was conceived as a convenient error of using terror to oppose a common enemy. That was not a simulacrum created by the media with the ire of satire or the error of terror but with the cynical deployment of the resources of the state to 'awe' determined opponents into submission until the snake that bites the enemy stings the sponsor with its tail. Failing to find enemies, security agents are known to entrap otherwise law-abiding citizens and then arrest them in preemptive moves against (T)error

1.10 Similarly, the training and funding of Islamic militants in Libya to facilitate the overthrow and killing of Gadhafi ended up with the error of terror being applied to the US consulate in Benghazi and to the ungovernmentality of Libya with predictable consequences for countries in Africa that then faced the sophisticated weapons in the armory of determined militants. Rather than be caused by the media, it is the case that media coverage of these other events has paled into insignificance compared to the deluge of attention on Paris and the pro-free speech march by state officials who themselves repress free speech at home.

1.11 The same error in the deployment of terror as a tool in international relations is perceptible in the strategy of training and arming militants in the Syria civil war and turning a blind eye to thousands of European citizens flooding to Syria to fight for 'freedom' only to kidnap westerners and behead them on camera while threatening with the Cockney accent of London working class elements. Michael Adebolajo was said to have been arrested by Kenyan police while trying to enter Somalia to join Al Shebaab in killing black Africans but it was alleged that UK security officials secured his release and tried to flip him as an intelligence agent to infiltrate Islamic groups in the UK but that apparently antagonized him more as he told the smart phone videographer with a perfect London accent that if you stop killing their people they would stop killing your people, ire for ire, terror for terror, all errors.

1.12 An attempt to theorize the error of terror or the ire of satire should not be confused with an attempt to justify them. Instead, the effort here is to answer that old sociological question of Hobbes: what makes society possible despite tireless attempts to impose the error of terror directly or indirectly as state policy? When the French-African rapper, Monsieur R released a video in which he dressed as a Gendarme and used the satire of white female nude dancers to critique the even more pornographic violence of French military interventions in Africa with the chorus that France is a bitch to be 'forcqued' to death and with the hook threatening to piss on General De Gaul and on Napoleon, he was promptly prosecuted in 2006 for indecency but the state is yet to apologize for its record of centuries of indecency against people of African descent.[11]

1.13 The difference between the events of Charlie Hebdo and the terrorism of the state is that the western state no longer deploys the error of terror in defence of a religion despite the mythology of some that the preemptory strikes against Iraq on false pretences were somehow divinely inspired while the Islamic militants swear that they were out to avenge the Prophet Imam and were prepared to die and go to paradise for their rewards in dozens of virgins. This is a difference in motivation but not a difference in strategy given that the error of terror is instrumentalized by all militants with weapons that are largely manufactured in the west and distributed across 
1.14 Rather than dwell on a blame game, the suggestion here is that sociologists should re-examine the institution of the state as one that institutionalizes the error of terror.[12] Sociologists should confess their own complicity in the enthronement of the error of terror as public policy because sociologists have rarely questioned the violence-prone fetishes of the state be it in Ferguson where US citizens were forced into reminding militarized police that arms up meant don't shoot or be it in Nigeria where extra judicial killings by the militarized lawenforcement agents were reported by Al Jazeera news to be part of the reasons for the radicalization of Boko Haram.

1.15 In other words, sociologists should reconsider the Marxist-Leninist concept of the withering away of the state to find ways to roll back the nanny state and allow more freedom to citizens who should have the right to dissent from whatever and be allowed the free space to express their dissent non-violently without fearing for their lives. In the original formulation, it was suggested that a revolutionary transformation of society will not result in the overnight abolition of the state but that gradually the state will wither away when it is no longer necessary to rely on force for the administration of things in a classless society. We are still far from a classless society but it is true that many laws have gradually withered away already - capital punishment, gambling, sex work in some jurisdictions, same-sex relationships in many jurisdictions, abortion in many jurisdictions, sedition, drugs prohibition in some jurisdictions, and witchcraft offences in most jurisdictions.

1.16 Sociologists should return to the theory of the withering away of law by Pashukanis[13] and stretch it to consider the withering away of militarism as an institution incompatible with the knowledge society of today. As John Lennon dreamed, let us imagine a world where there is no more war, where arguments are settled in a civil manner with social media and not with bombs and hell fire missiles. Instead of training fighters and arming them to go and overthrow perceived enemies, it may be necessary to develop theories that will guide policy towards the training of lovers to go and develop love, teachers to go and educate the illiterate and doctors to go and cure the sick as Cuba did in West Africa during the Ebola epidemics while the UK and the US responded by sending the hammer of their military, thinking that just because they have good hammers every problem must be a nail.

1.17 The Africana philosophy of non-violence that Gandhi claimed that he learned from the warlike Zulu[14] promises to be a sociologically sophisticated and methodologically validated response to the error of terror and the ire in satire. Echoing this philosophy in three speeches in 1968 about the non-violent response to the error of Jim Crow terrorism, about the terror in Vietnam and about apartheid South Africa, Martin Luther King Jr. reminded the world that we are like the descendants of a great writer who left a 'World House' to be inherited by us all: we must learn to live together peacefully and in love or fight and burn the house down.[15] Chinua Achebe drew from his Igbo culture to identify the world house as Mbari, a miniature sculpture that is made by the entire community and with each race, gender and class represented under one roof.[16] Desmond Tutu used the philosophy of Ubuntu or the bundle of humanity to represent the same concept of forgiveness and loving kindness as the best response to the error of terror and the ire of satire.[17] Sociological theory should pay attention to these original theoretical developments and move away from the navel-gazing obsession with only the ideas of dead white men especially when looking for solutions to the error of terror that is rooted in the foundation of fundamentalism in the philosophy of patriarchal imperialist white supremacy.

\section{Notes}

Andress, David (2006). The Terror: The Merciless War for Freedom in Revolutionary France New York: Farrar, Straus and Giroux.

Ryan Michael Spitzer, "The African Holocaust: Should Europe pay reparations to Africa for Colonialism and Slavery?", Vanderbilt Journal of Transnational Law, vol. 35, 2002, p. 1319.

Michael Mann, 2005, Incoherent Empire, London, Verso.

Chinua Achebe, 2012, There Was A Country: A Personal History of Biafra New York, Penguin; see also Hebert Ekwe-Ekwe, 2006, Biafra Revisited, Dakar, African Renaissance. 
Symposium on Obscenity in Folklore (Jul. - Sep., 1962), p. 209-220.

On Cosmopolitanism and Forgiveness, trans. Mark Dooley \& Michael Hughes (London \& New York: Routledge, 2001).

http://www.theguardian.com/uk-news/2015/jan/12/make-universities-exempt-from-counter-terror-duty .

http://www.chomsky.info/articles/19801011.htm.

Jean Baudrillard."The Mirror of Terrorism." in: James Benedict (Translator). The Transparency of Evil: Essays on Extreme Phenomena. Verso Books. June 1993.

1967 The Medium is the Massage: An Inventory of Effects with Quentin Fiore, produced by Jerome Agel; 1st Ed.: Random House; reissued by Gingko Press, 2001.

Angelique Chrisafe, 'Rapper Faces Jail for Dissing France' in The Guardian, 28 May, 2006: http://www.theguardian.com/world/2006/may/29/france.arts.

Poulantzas, Nicos. State, Power, Socialism. NLB, 1978.

http://www.marxists.org/archive/pashukanis/1936/04/statelaw.htm.

Gandhi, Mohandas Karamchand (1928). Satyagraha in South Africa(in Gujarati) (1 ed.). Ahmedabad: Navajivan Publishing House.

Martin Luther King, Jr. (2010). Where Do We Go from Here: Chaos Or Community?Beacon Press.

Achebe, Chinua (2012) There Was A Country, New York, Penguin.

Kamwangamalu, Nkonko M. (2014). Ubuntu in South Africa: A sociolinguistic perspective to a panAfrican concept. In Molefi Kete Asante, Yoshitaka Miike, \& Jing Yin (Eds.), The global intercultural communication reader (2nd ed., p. 226-236). New York, NY: Routledge. 